\title{
The Effect of Work-life Balance Policies on the Retention Intention of Executive Women Employee in Information Technology (IT) Industry in Sri Lanka
}

\author{
Bhagya Sumanarathna $^{1}$ and S. M. A. K. Samarakoon ${ }^{2}$ \\ ${ }^{1}$ Postgraduate Student, Master of Business Administration, Department of Commerce \\ and Financial Management, University of Kelaniya, Sri Lanka \\ ${ }^{2}$ Senior Lecturer, Department of Commerce and Financial Management, University of \\ Kelaniya, Sri Lanka \\ ${ }^{1}$ bhagieka2008@gmail.com, ${ }^{2}$ samarakoonak@kln.ac.lk
}

\begin{abstract}
Female employee labor turnover of information technology industry in Sri Lankan is in the higher level. Therefore, the general objective of the research is to assess the impact of major work life balance policies influence on retention of executive women employees in Information technology organizations in Sri Lanka. Five selected work-life policies namely flexible working hours, company leave policy, training and career development opportunities, compressed workweek and workload management were examined with employee retention. Base on random sampling method one hundred two completed questionnaires used to analyze the data. Descriptive statistics, correlation and multiple regression utilized to analysis the data. Work-life balance and employee retention levels are in the satisfactory level in the IT industry in Sri Lanka. Multiple regression result of the study shows that work-life balance policies positively influence on the executive women employee retention. Selected five policies of work-life balance and employee retention were examined using multiple regression model. Training and career development opportunities and workload management positive influence on employee retention. Although rest of three work life balance policies namely flexible working hours, company leave policy and compressed work week didn't show the significant impact of employee retention. Policymakers and top management of companies should improve work-life balance to increase employee retention. Moreover, they can use training and career development opportunities and workload management to increase employee retention.
\end{abstract}

Keywords: Work-life Balance Policies, Retention Intention, Women Employees

\section{Background of the Study}

Today people have a busy lifestyle and don't balance their job with their private life; it seems they go far from their family and their private lives. With fastdeveloping technology and notable business organization competition, persons have converted like machines. Workers must work longer hours and days to face their workplace difficulties. Besides, employers also attempt to decrease their employees' benefits to increase the profit of their organization. This situation creates an imbalance of employment for staff, and it leads to a bad relationship between employer and employee (Carmichael, 2015). 
Aravind and Paramashivaiah (2011) mentioned that due to unhealthy job practice all over the globe, issues had increased dramatically in recent years. Since work-life balance practices are becoming compulsory factors that must be implemented in a business organization to have profits and sustainability by increasing productivity and as well as motivating and retaining a talented workforce. On the other side, due to employees' occupation and income, they tend to work anytime, according to the supervisors' request. With the continuous practice of this, family members always miss their loved ones, and most of the time, they have to spend time separated in two different places (Carmichael, 2015). Deivasigamani and Shankar (2017) mentioned that if employees achieve work life balance, it leads to achieving the employer's objectives.

People work to earn money to live, to meet and meet their loved ones' requirements and wishes. But if you don't have enough time to live with your loved ones and face distinct types of issues because of the work you do, a gap between your work- life and your private life can be established. This conflict is a common situation, as it takes more stuff at home and the welfare of kids into question when you consider a woman worker and an organization. Therefore, work- life balance facts and their implementations are very important for a working woman and sometimes she has to make hard decisions when the worklife conflict become serious. It seems that in our nation, many of the women staff in organizations hold top positions. They are individuals with more education, talent and organizational responsibility. But because of the unhealthy balance between work and home, they sometimes tend to leave the job. Therefore, if an organization practices excellent practices to improve the standard of life of its staff and make it easier for skilled females to maintain their staff. Alison (2015) mentioned that installation of work-life balance practices making better all career stages of employees at working place.

IT industry in Sri Lanka today has become an immense earning industry which is fast growing. The men and women in the IT industry have careers such as Computer engineer, computer programmer, computer scientist, computer user, database administrator, database specialist, interface designer, network specialist, software engineer etc. Lilian Njeri Njenga, (2014) mentioned that women all over the world face a double burden of productive (paid work) and reproductive work.

Carucci (2016) mentioned that it makes a convincing case for female leadership in the current business world. He says many types of research around the world the presence of female executives on corporate boards leads to higher profitability (Carucci, 2016). Fisher (2013) has explained in his article the way women resolve problems as, when women think, they gather details somewhat differently than men. Women integrate more information faster and arrange these bits of data into more complex patterns and broader areas. As they make decisions, women tend to weigh more variables, consider more options, and see a more extensive range of possible solutions to a problem.

Women were represented $33.6 \%$ of the total labour force of Sri Lanka (Department of Census and Statistics, 2018). They are working engaging 
country, and most educated and talented women are working in both government and private sectors (Wanninayake, 2017). Moreover, Women like to continue to work in a specific firm primarily in the government body their employments gives opportunity them to attained to additional private problems. Therefore, women are bearing a higher burden of voluntary work in the household. Family care responsibilities predominantly fall on women, thus potentially having an impact upon their ability to balance work and family life; consequently, limiting their labour market participation. Work-life conflict arises when employees, especially women, are unable to balance their domestic or personal responsibilities and their work obligations. Work-life conflict is one major cause of employees' turnover from organizations. Moreover, poor work-life balance will be poor performance, absenteeism, sick leave and higher staff turnover, recruitment and training costs (Department of Trade and Industry, 2001).

\section{Statement of the Problem}

International Labor Organization (2016) mentioned that the highest proportion of women employees in executive and management grade in the Information technology sector was $45 \%$. Therefore, having a clear idea about retain executive women may help to reduce future women employee job quits. It may help to implement work-life balance practices within the organization in the future. That may help for employees as well as employers. Work-life balanced women employees are full of job satisfied, and the outcome of them is remarkably higher than frustrated employees. Because of the continuous unbalanced work style in some organizations, many employees have to leave their jobs (Aravind \& Paramashivaiah, 2011). In 2017, the department of senses and statistics conducted an employee survey and published its report. According to the report, the total number of female resignations was at a higher level (Labour Demand Survey, 2017) and it is increasing year by year. Further, there is much research conducted to find out factors influence on work-life balance and its effect on employee retention. However, there are limited research in the field of work-life balance and its impact on retention of women employees in Sri Lanka context. Moreover, the lack of research in the work-life balance and retention in the information technology industry. Nevertheless, it is difficult to find out the research article on the effect of work-life balance policies on retention intention of executive women employees in the Information technology sector in Sri Lanka.

\section{Research Objective}

The objective of the research is to assess the impact of major work-life balance policies on retention intention of executive women employees in Information Technology (IT) firms in Sri Lanka.

\section{Literature Review}

Work-life balance as the extent to which an individual is equally involved and equally fulfilled with his or her work and family role (Greenhaus, Collins \& Shaw, 2003). Many studies have been conducted on searching the link between work-life balance and job outcomes such as employee commitment, job satisfaction, and higher productivity (e.g. Virick, Lily \& Casper, 2007, Doherty \& 
Manfredi 2006). Alternatively, Worklife conflict has a significant positive relationship with turnover intentions. Since, companies must develop the environment to support and upkeep the flexibility of conducting work and their personal life (Noor \& Maad, 2008). Therefore, firms pay attention to involve the amendments in human resource policies to retain a decent blend of employee personal lives with their career developments.

\section{Work-life Balance Policies}

Mishra (1996) model asserts that quality of life is a function of the income and educational background of the employees, whereby higher income and education levels lead to a high quality of life. Higher quality life of employee significant for the success of the working place. In addition, Ellis and Pompli (2002) identified poor working environments, resident aggression, workload, inability to deliver preferred quality of care, work-family balance, shift work, involvement in decision making, recognition, relationships with supervisor/peers, and opportunity to learn new skills as factors that contributes to quality of working life in nurses.

Alison and Hall (2015) have argued that work-life balance is where employees meet their needs in both work and nonwork environment of life. When they experience great work-life balance, they feel better. They tend to behave in favourable ways in both their personal lives and workplace. They tend to be involved with minimum conflicts in their lives and have a higher level of satisfaction with their job and life. When they have a lower level of stress and depression, it may cause to attract new hires, reduce turnover, absenteeism and by increasing voluntary engaging can improve productivity as well. Ratna and Kaur (2016) in his article based on IT sector revealed that the work-life of an employee had attracted a great concern because of a large number of problems related to employee health, monotony at the workplace, declining levels of productivity and competence at the employee level. Further, he mentioned that work-life balance diminishes as age increases and female employees require a flexi work environment and timings, a healthy relationship with colleagues helps in maintain the balance. So, organizations should provide provisions for the development of oneself, support family needs, a flexible work culture with management support. Several researchers identified number of commonly used work-life balance practices such as; flexible working hours, telecommuting, job sharing, compressed workweek, childcare facilities, family leave programs, part-time work arrangements, organizational culture, paid maternity leaves, education assistance and health assistance(Faheem \& Bukhari, 2012; Alison \& Hall, 2015).

Wei \& Yazdanifard (2014) mentioned that flexible working hours are becoming essential to workplaces. Greater employee productivity and higher organization profitability are the most common benefits. In addition, flexible working hours promote and facilitate work-life balance. Reduced stress and increased employee wellbeing are outcomes of the work-life balance. Moreover, Shagvaliyeva and Yazdanifard (2014), work flexibility implies not the only variation in time and place of the job, but also sharing of the 
job, career breaks (maternity/paternity leaves), part-time and term-time working. Job sharing is a situation in which two workers or employees share the responsibilities and benefits of a single full-time position (Gliss, 2000). It refers to a voluntary arrangement in which employees (usually two), with the approval of their employer, share a single job on an ongoing basis. Two people voluntarily share the responsibilities of one full-time job, allowing employers to retain valued employees who prefer to work part-time (Singh, Goolsby, and Rhoads, 1994). Moreover, Lee and Cummings (2008) in their systematic review on job satisfaction in front line managers, highlights the importance of flexibility in job sharing and the importance of job satisfaction in retaining employees.

Pitt and Ramaseshan (1995) found that persons who show a higher tendency to leave their jobs were those who supposed that the job previews that they received through the interview procedure were not accurate. Firth, Mellor, Moore and Loquet, (2004) found that emotive care from supervisors and self-esteem mediated the effect of stressors on stress reactions, job satisfaction, commitment to the organization and purpose to quit. It is proposed that to improve intention to leave and in turn, decrease turnover, managers' necessity to monitor workloads and the associations between supervisors and subordinates actively. Monitoring workloads and supervisorsubordinate relationships by management may reduce intention to quit and consequent turnover, thereby saving organizations the significant financial cost and effort involved in the recruitment, induction and training of additional staff. In studies associated with payment, Park, Ofori- Dankwa, \& Bishop, (1994) and Trevor, Barry, \& Boudreau (1997) found that pay growth had a noticeable effect on turnover. Mostly, salary growth effects on turnover were greatest for the best players, that is, high salary growth significantly reduced turnover for high performing employees. Abassi and Hollman (2000) in their study have recognized a lack of recognition, and lack of competitive compensation systems are some motives for employee turnover in the companies. Miller and Wheeler (1992) found that the nonexistence of meaningful work and openings for promotion significantly affected employees' intentions to leave their companies. Organizations were able to increase their employees' retention rate by adopting job enrichment programs and enhancing their advancement opportunities. Besides promotion chances, the evaluation criteria used in the promotion and reward system also had significant effects on employees' turnover intentions (Quarles, 1994). Unproductive performance appraisal and planning systems contributed to employees' perceptions of unfairness, and they were more likely to consider exiting the organization (Dailey \& Kirk, 1992).

The concept of job burnout has been used to explain employees' chronic and cumulative job stress in the workplace (Babakus, Yavas \& Ashill, 2009; Halbesleben, 2006; Sand \& Miyazaki, 2000). Job burnout refers to the state of psychological strain that an employee experiences because of chronic job stress (Halbesleben, 2006). Several studies have found a positive relationship between job burnout and turnover intentions in diverse settings (Schaufeli \& Bakker, 2004; Singh et al., 1994). A 
high level of job burnout causes employees to feel depressed and experience a sense of failure, fatigue, and a loss of motivation, which in turn can lead to a number of problems for the organization, including employee turnover, absenteeism, and reduced organizational commitment, morale, job satisfaction, and productivity (Halbesleben \& Buckley, 2004). The decision-makers of the firms must identify the work plan that may help to the work-life balance of employees because Manning (2003) revealed that finding a job and taking a job to a top position is prevented by women commitment for their families than men in the United Kingdom. Further, Kumarasamy et al. (2015) stated that Individual factors, organizational factors and Environmental factors influence work-life balance. Department of Trade and Industry states that work-life balance is not only about families and about childcare. Nor is it about working less. It is about working smart. About being fresh enough to give all you need to both work and home, without jeopardizing one for the other. And it's a necessity for everyone, at whatever your stage in life." (Department of Trade and Industry, 2001).

The work-life policy is any program, which rises company capability to fit in the needs of work and personal life of employees. Work-life policies spread beyond the traditional concept of familyfriendly, and it takes many practices such as time base practices and other practices. Base on the literature and discussion with academic and professionals' expert in the field researcher identified five types of worklife balance policies namely working hours; Company leave policy, Training and career development opportunities, compressed workweek and workload management.

Flexible working hours - Flexible working policy can be allowed to alter their working hours in order to utilize time for relaxations, children work, channeling doctors, family work et. Moreover, it provides to spending time with their families. Since flexible work arrangement was identified as an essential part of work-family support (Pasewark \& Viator, 2006).

Company leave policy - Leave policies are becoming an advantage that can benefit any firm to attract and retain top performers. Therefore, companies prepare the effective leave policy after considering the work-life balance.

Training and career development opportunities - Training and development support to lower turnover rate and considered as an important factor in employee retention (Wetland, 2003). Further, Sophia \& Ali (2011) mentioned that companies must attempt to ensure that programs for career development amongst women employees.

Workload management - Companies must manage the workload because researchers find that additional workload and stress on remaining staff, increasing job dissatisfaction (Moseley, Jeffers and Paterson, 2008). Since work load management policy was identified as a significant factor that may effect to employee retention intention.

Flattened workweek - It is an arrangement of work hours that allows employees to complete their tasks less than usual 5 working days. Ex: Instead of 
8 hours per day for a week work schedule, the employee can cover a total forty hours per week using any other schedule.

\section{Employee Retention}

Holtom (2008) Managers have implemented human resources policies, and practices to active reduce avoidable and undesirable turnover of employees. Managing retention of promising employees is considered as a primary mean of achieving competitive advantage amongst organization (Walker, 2001). Although high employee turnover is an organization is a symptom of a burning issue that has not been resolved. Employee retention is simply the ability of an organization to retain its employees. There may be some reasons for that such as low employee morale, absence of a clear career path, lack of recognition, poor employeemanager relationships or many other issues. In a business form, every employer gets an effort to reduce employee turnover. Thereby hope to decrease training costs, recruitment costs and to stop the loss of talent and organizational knowledge. The expenses related to directly replacing an employee can be as high as $50-60 \%$ of the employees' annual salary. Still, the total cost of turnover can reach as high as 90$200 \%$ of the employee's yearly salary. These costs include seeking candidates, newly hired employee training, the recruiter's salary, separation processing, and job error, loss of sales, reduced existing employees' morale and several other costs to the organization. (Newman, 2008). Somehow, organizations will be unsuccessful in implementing inappropriate retention strategy (Heathfield, 2017). Employee retention is essential for an organization to have a competitive advantage in today's competitive business world. Providing emotional support and worklife balance to employees helps organizations to maintain a low turnover (Karatepe, 2013).

Later \& Heathfield (2017) has discussed employee retention in many ways. First has mentioned that retain key employees is critical to the long term health and success of any business. Keeping the best employees ensures customer satisfaction, product sales, satisfied coworkers and reporting staff, effective succession planning and deeply implanted organizational knowledge and learning. Heathfield (2017) mentioned employee's retention had become one of the primary measures of the health of your organization.

The attraction and retention of a highquality employee are more important today than ever before. Some of the trends like globalization, increase in knowledge work and technological advancement make it essential that firms acquire and retain human capital. As a response to this Deery (2008) has further argued about the importance of the worklife balance of employees on employee retention as, the role of work-life balance has a direct relation in employee's decision to stay or leave the organization. Job attitudes such as job satisfaction and commitment, personal reasons such as positive and negative feelings, the role of work-life balance in employee attrition and finally, all these strategies provided reasons to reduce high turnover rates. Base on the literature researcher developed the following conceptual framework for the study. 


\section{Conceptual Framework and Hypothesis}

Base on the literature review (e.g. Ellis \& Pompli, 2002; Mishra, 1996; Later \& Heathfield, 2017) and discussion with expert in the field, researcher has selected five work-life balance policies namely flexible working hours, company leave policy, training and career development opportunities compressed workweek and workload management were identified as independent variables, which can be influenced on women employee retention intention. Figure 01 shows the conceptual framework of the study.

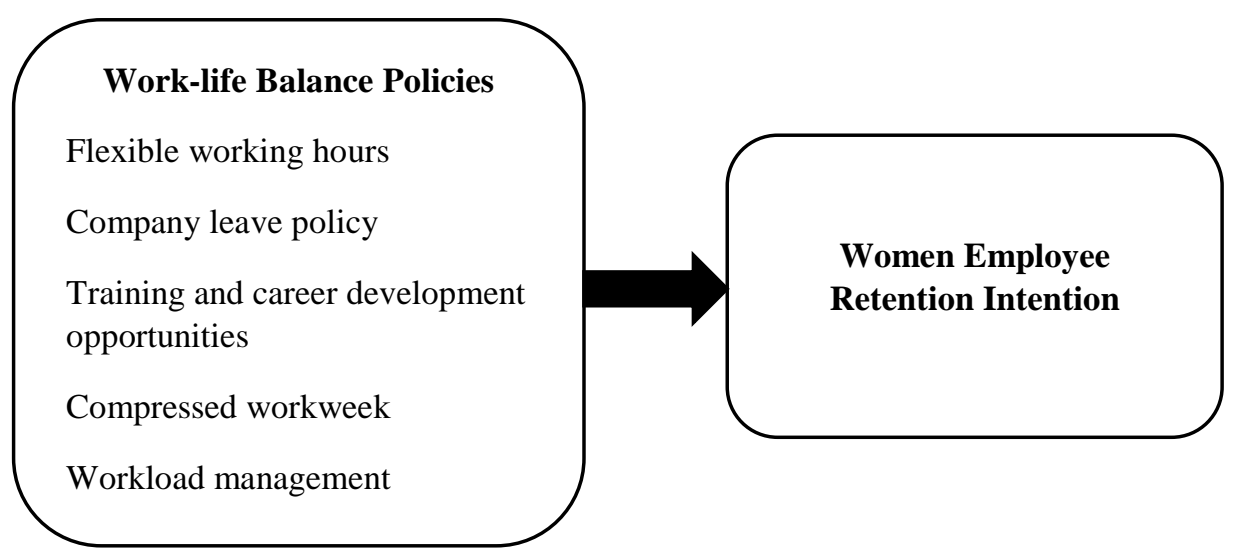

Figure 01: Conceptual Framework

Source: Authors, 2018

Many researchers' identified (e.g. Faheem \& Bukhari, 2012; Alison \& Hall, 2015) influence of work-life balance policies impact on employee retention intention. Therefore, the author assumes that

H1: Work-life balance policies are significant predictors of executive women employees' retention intention in the Information Technology industry in Sri Lanka.

Ho:- Work-life balance policies are not significant predictors of executive women employees' retention intention in the Information Technology industry in Sri Lanka.

\section{Materials and Methods}

IT industry was dominated by the private firms in Sri Lanka. Therefore, the study was conducted using private IT companies. The total population of the study is all women executives in the private IT companies in Sri Lanka. The researcher has selected one hundred and two women executive employees who are working in the five companies, which are registered in SLASSCOM with more than 500 employees. Fourth women executive employees were selected using random sampling method from each organization and data were gathered using a standard questionnaire by using 
Google forms. Questions of the questionnaire were divided into three parts, namely demographic factors and questions of work-life balance and employee retention. Work-life balance policies and retention intention were assessed by five-point Likert scale adopting standard questionnaires taken from Luthans (2002), Anon (2003) and Sonjibu (2011). Descriptive statistic tools used to analysis of demographic data. Regression analysis was used to test the hypothesis among work-life balance policies and employee retention. SPSS 23 was used for the data analysis.

\section{Analysis and Results}

Demographic factors were analyzed using SPSS 23. Age analysis shows 53\% of employees sample employees are from 25-35 years age group and the lowest percentage represent age group of above 45 years, with $12 \%$ of the sample. Next important demographic factors, which are linked with work-life of women employees, are marital status, number of children, working experience etc. Marital Status is a significant factor in the lifestyle of respondents. It was analyzed using four categories (Single,
Married, Divorced and widowed), and the majority of respondents are married with $55 \%, 34 \%$ of single respondents and $11 \%$ represent divorced and widowed. Married category $50 \%$ of the sample having 1-2 children, $25 \%$ having 3-4 or above 5 children of the sample and rest of women employees have not children. Moreover, widowed respondents have children between 3-4 children. Majority of the respondents (40\%) have 6-10 years' experience and $34 \%$ of respondents have been working less than 5 years working experience $20 \%$ of respondents were under 11-15 years category, and rest of $6 \%$ were under over 15 years category.

Designation of was recorded using five categories defined (Executive, Junior Executive, Middle Manager, Senior Manager, Top Management). Majority of the respondents $(35 \%)$ were middle managers in the organizations, and $27 \%$, $13 \%$ and $12 \%$ of respondents were executives, junior executives and senior managers respectively. Table 01 shows the Cronbach's alpha coefficient values of independent and dependent variables and all values are higher than 0.7 ( Hair et al., 1998).

\section{Table 01: Reliability Statistics}

\begin{tabular}{|c|l|c|c|}
\hline No & \multicolumn{1}{|c|}{ Variable/s } & $\begin{array}{c}\text { Cronbach's } \\
\text { Alpha }\end{array}$ & $\begin{array}{c}\text { Number of } \\
\text { Items }\end{array}$ \\
\hline 1 & Independent- Flexible Working hours & 0.816 & 6 \\
\hline 2 & Independent-Company leave policy & 0.713 & 5 \\
\hline 3 & $\begin{array}{l}\text { Independent-Training and career } \\
\text { development opportunities }\end{array}$ & 0.881 & 4 \\
\hline 4 & Independent- Compressed work week & 0.878 & 5 \\
\hline 5 & Independent-Workload management & 0.829 & 6 \\
\hline 6 & Dependent-Employee Retention & 0.775 & 5 \\
\hline
\end{tabular}

Source: Survey data, 2018 
The study assessed the level of work-life balance of executive women employees of the IT industry in Sri Lanka. Table 02 shows the satisfactory level mean value (3.71) with minimum 3 and maximum 5 values.

Table 02: Descriptive Statistics - WB

\begin{tabular}{|l|c|c|c|c|c|}
\hline & $\mathrm{N}$ & Minimum & Maximum & Mean & Std. Deviation \\
\hline $\begin{array}{l}\text { Work-life } \\
\text { Balance(WB) } \\
\text { Valid N (list-wise) }\end{array}$ & 102 & 3 & 5 & 3.71 & .360 \\
\hline
\end{tabular}

Source: Survey data, 2018

The study measured the retention level of executive women employees and Table 03 shows 3.45 satisfactory level mean value with minimum 2 and maximum 5 for the executive women employees of IT industry in Sri Lanka.

Table 03: Descriptive Statistics - ER

\begin{tabular}{|l|c|c|c|c|c|}
\hline & N & Minimum & Maximum & Mean & Std. Deviation \\
\hline Employee & 102 & 2 & 5 & 3.45 & .752 \\
Retention(ER) & 102 & & & & \\
Valid N (list-wise) & & & & \\
\hline
\end{tabular}

Source: Survey data, 2018

Table 04 shows the model summary of SPSS output of simple regression analysis work-life policies and employee retention. Further, the model around 29\% variation ( $\mathrm{R}$-value 0.54 and $\mathrm{R}$ squire value 0.284) was explained by the selected factor. It means $29 \%$ of women employee retention intention depend on work-life balance.

Table 04: Simple Regression - Model Summary

\begin{tabular}{|c|c|c|c|c|}
\hline Model & $\mathrm{R}$ & $\mathrm{R}$ Square & Adjusted R Square & Std. Error of the Estimate \\
\hline 1 & $.540 \mathrm{a}$ & .291 & .284 & .636 \\
\hline
\end{tabular}

a. Predictors: (Constant), Work life Balance(WB)

Source: Survey data, 2018

Table 05 shows the summary of coefficient value of overall work-life balance policies significantly influence the executive employee retention 
intention of IT industry in Sri Lanka. balance policies significantly influence According to the result work-life, the employee retention.

Table 05: Coefficients

\begin{tabular}{|c|c|c|c|c|c|}
\hline \multirow{2}{*}{ Model } & \multicolumn{2}{|c|}{$\begin{array}{c}\text { Unstandardized } \\
\text { Coefficients }\end{array}$} & $\begin{array}{c}\text { Standardized } \\
\text { Coefficients }\end{array}$ & \multirow{2}{*}{ t } & \multirow{2}{*}{ Sig. } \\
\cline { 2 - 4 } & $\mathrm{B}$ & Std. Error & Beta & \\
\hline \multirow{2}{*}{1} & -.732 & .655 & & -1.117 & .267 \\
\hline $\begin{array}{l}\text { (Constant) } \\
\begin{array}{l}\text { Work life } \\
\text { Balance } \\
\text { policies(WBP) }\end{array}\end{array}$ & 1.127 & .176 & .540 & 6.410 & .000 \\
\hline
\end{tabular}

a. Dependent Variable: Employee Retention Intention (ER)

Source: Survey data, 2018

Subsequently, researcher analyzed influence of each work-life balance policies on employee retention using multiple regression model. Table number

06 shows SPSS model output of selected 5 independence variables and employee retention. The model explained $40 \%$ of variation of employee retention.

Table 6: Multiple Regression - Model Summary

\begin{tabular}{|l|r|r|r|r|}
\hline Model & \multicolumn{1}{|c|}{$\mathrm{R}$} & \multicolumn{1}{c|}{ R Square } & \multicolumn{1}{c|}{$\begin{array}{c}\text { Adjusted R } \\
\text { Square }\end{array}$} & \multicolumn{1}{c|}{ Std. Error of the Estimate } \\
\hline 1 & $.654^{\mathrm{a}}$ & .427 & .397 & .584 \\
\hline
\end{tabular}

a. Predictors: (Constant), Work load(WL), Compressed week(CWW), Flexible working hours(FWH), Training and career development opportunities(TCDO), Company Leave Policy(CLP)

Source: Survey data, 2018

Table number 07 shows the summary of multiple regression analysis result. According to multiple regression result, training and career development opportunities and Workload management positively influence on employee retention within the IT industry in Sri Lanka. It means, greater the training and career development opportunities and compressed working

week lead to increase work-life balance. Working hours, Company leave policy and compressed workweek do not show the significant influence on employee retention within the IT industry. Because, most of IT companies in Sri Lankan prepared their working hours and leave policy after considering employee requirements. 
Table 07: Multiple Regression Model Result

\begin{tabular}{|c|c|c|c|c|c|}
\hline \multirow[t]{2}{*}{ Model } & \multicolumn{2}{|c|}{$\begin{array}{l}\text { Unstandardized } \\
\text { Coefficients }\end{array}$} & \multirow{2}{*}{$\begin{array}{c}\text { Standardized } \\
\text { Coefficients } \\
\text { Beta } \\
\end{array}$} & \multirow[t]{2}{*}{$\mathrm{t}$} & \multirow[t]{2}{*}{ Sig. } \\
\hline & B & Std. Error & & & \\
\hline (Constant) & .963 & .721 & & 1.334 & .185 \\
\hline $\begin{array}{l}\text { Flexible working } \\
\text { hours(FWH) }\end{array}$ & .123 & 102 & .099. & 1.203 & .232 \\
\hline $\begin{array}{l}\text { Company Leave } \\
\text { Policy(CLP) }\end{array}$ & .139 & .096 & . 132 & 1.445 & .152 \\
\hline $\begin{array}{l}\text { Training and career } \\
\text { development } \\
\text { opportunities(TCDO) }\end{array}$ & .167 & .070 & .203 & 2.368 & .020 \\
\hline $\begin{array}{l}\text { Compressed work week } \\
\text { (CWW) }\end{array}$ & .002 & .085 & .002. & .020 & .984 \\
\hline $\begin{array}{l}\text { Work load management } \\
\text { (WL) }\end{array}$ & .522 & .106 & .471 & 4.907 & .000 \\
\hline
\end{tabular}

a. Dependent Variable: Employee Retention intention (ERI)

Source: Survey data, 2018

\section{Discussion}

The key objective of the study is to examine the impact of work-life balance on retention of executive women employees of the IT industry in Sri Lanka. One hundred two questionnaires were used to the final data analysis. Descriptive statistics and multiple regression utilized to analysis the data. According to descriptive analysis result, the highest percentage of employees represent 25-35 years age group, the lowest percentage represent above 45 years old respondents. The majority of executive women employee represent the middle age group with children. Since top management of IT, industry must give their attention to raise work -life balance of women employees in the IT industry. Moreover, the majority of respondents are married having 1-2 children with 6-
10 years' working experience in middle management.

This study has measured the level of work-life balance of executive women employees and measured the retention intention level of executive women employees. Employee retention intention level is in the satisfactory level in the Sri Lankan IT industry. Further, overall work-life balance policies positively influence on the executive women employee retention intention in the IT industry in Sri Lanka. Past research, findings also found a similar positive influence on employee retention intention (E.g. Later \& Heathfield, 2017; Alison \& Hall, 2015). Since it is essential to advance the existing significant worklife balance related human resource policies and awareness of employees on work-life balance. Among the five work-life policies, two dimensions of 
work-life balance, namely training and career development opportunities and workload management significantly influence employee retention intention. Many past researchers (E.g. Sophia \& Ali, 2011; Wetland, 2003) confirmed influence of training and career development opportunities and workload management. On the other hand, flexible working hours, company leave policy and compressed workweek did not show a significant impact on employee retention intention in the Sri Lankan IT industry.

\section{Conclusion}

A large part of women employees represent middle age group with children, and employee retention intention level is in the acceptance level. Moreover, training and career development opportunities and workload management significantly affect employee retention intention. Therefore, top management of IT companies should formulate a proper workload management system after considering employee requirements. Besides, employee feedback and employee comments on previous training programs should consider before design the new training programs. Although, flexible working hours, company leave policy and compressed workweek did not show a significant influence on employee retention intention in the IT industry.

\section{Recommendations}

Work-life balance is a broader concept, and both parties (employees and Flexible working hours, company leave policy, training and career development opportunities, compressed work week and work load management. This employer) must pay attention to improve work-life balance. The first recommendation is; top management of IT firms should provide their attention to advance their training and career development opportunities and workload of executive women employees because both factors significantly influence on employee retention. Effective workload management training programs can include evaluating present work-life balance program and it influence on employee, shortcomings of existing programs and plans for developing the individual life and organizational goals etc. Second recommendation is; Company should organize awareness programs on the influence of work-life balance at workers private life and organizational life. It can achieve using life management training programs, which are important to identify lifestyle challenges and issues. This type of programs lead to make significant life style changes. Moreover, firms must find out, what types of work-life balance policies suitable for their organizations.

\section{Limitations and Directions for Future Research}

Main limitation of the study is selected only one hundred two executive employees who working in the IT companies registered in SLASSCOM with more than 500 employees in Sri Lanka. Number of work life policies may influence to employee retention intention although researcher has selected only five policies namely

research was limited to IT industry, future researchers can conduct the studies based on various manufacturing companies, services etc. Moreover, 
employee retention depend on number of other factors (e.g. compensation, Salaries, working environment), since future research can conduct including work-life balance and other factors that may influence to employee retention.

\section{References}

Abassi, S. M. \& Hollman, K. W. (2000), Turnover: the real bottom line, Public Personnel Management, 2(3): 333-42.

Abeysekera, R. (2007). The Impact of Human Resource Management Practices on Marketing Executive Turnover of Leasing Companies in Sri Lanka. Contemporary Management Research, 3(3). https://doi.org/10.7903/cmr.94

Adikaram, D.S.R. (2016). Impact of Work Life Balance on Employee job Satisfaction in Private Sector Commercial Banks of Sri Lanka, ISSN: 2313-3759, 17-31.

Alison \& Hall (2017). Work Life balance, Society for industrial and organizational psychology, 01, 125-132.

Anonymous (2003). Gold and Silver Employee Satisfaction Survey Programs. The Business Research Lab, LLC. <http://www.busreslab.com>.

Aravind .S K. \& Paramashivaiah S., (2011), A research study on managing work-life balance by international journal of knowledge and research in management \& E-Commerce, 1(2). 18(2):40.

Armichael, S. (2015). The research is clear: long hours backfire for people and for companies, Harvard Business Review, 19 August. Available at: https://hbr.org/2015/08/the-research-is-clear-long-hours-backfire-for-peopleand-for-companies (Accessed: 20 Oct 2019).

Babakus, E., Yavas, U., \& Ashill, N. J. (2009). The role of customer orientation as a moderator of the job demand-burnout-performance relationship: A surfacelevel trait perspective. Journal of Retailing, 85(4), 480-492. https://doi.org/10.1016/j.jretai.2009.07.001

Carmichael, S.G. (2015). Managers want to put their Employees for long, Harvard Business Review.

Carucci, R., Four Reasons Women Make Great Executives; Book of Rising to Power. https://www.forbes.com/sites/roncarucci/2016/05/10/four-reasons-womenmake-great-executives/\#5db26954691e

Dailey, R. C. \& Kirk, D. J. (1992). Distributive and procedural justice as antecedents of job dissatisfaction and intent to turnover. Human Relations, 45(3): 305-317.

Deery, M. A \& Iverson, R. D. (1996). Enhancing productivity: intervention strategies for employee turnover. N. Johns (Ed.), Productivity Management in Hospitality and Tourism, Cassell, London 
Deivasigamani, T. \& Shankar (2017). Dimension of Work Life Balance in Software Companies, Asian Journal of Applied Sciences, 05(02), 303-307.

Department of Census and Statistics Sri Lanka, Ministry of National Policies and Economic Affairs, Labor Demand Survey -2017. ISBN 978-955-702-066-2

Department of Census and Statistics, (2018). Sri Lanka Labor Force Survey Annual Report.

Department of Trade and Industry, (2001). The Essential Guide to - Work-life Balance. London: DTI. Available from: http://www.flexibleworking.co.uk/Juggle\%20Not\%20Struggle.pdf

Doherty, L \& Manfredi, S 2006, Action research to develop work-life balance in a UK university, Women in Management Review, 21(3), 241-59.

Ellis, N., \& Pompli, A. (2002), Quality of working life for nurses, Commonwealth Dept of Health and Ageing, Canberra.

Factors affecting women's labor force participation in Sri Lanka / International Labor Organization, (2017 2nd version), Labor Force Sri Lanka Annual Report.

Firth, L., Mellor, D. J., Moore, K. A. and Loquet, C. (2004). How can managers reduce employee intention to quit? Journal of Managerial Psychology, 19(2): 170-187.

Gliss, R. (2000). Job Sharing: An Option for Professional Nurses. Nursing Economics, $18(2): 40$.

Greenhaus, JH, Collins, KM \& Shaw, JD 2003, The relation between work-family balance and quality of life, Journal of Vocational Behavior, 63, 510-31.

Hair, J. F., Black, W. C., Babin, B. J., Anderson, R. E., \& Tatham, R. L. (1998). Multivariate data analysis (Vol. 5, No. 3, pp. 207-219). Upper Saddle River, NJ: Prentice hall.

Halbesleben, J.R.B. \& Buckley, M.R. (2004).Burnout in Organizational Life, Journal of Management, 30(6):859-79.

Jinadasa, L., \& Wickramasinghe, V. (2005, December). IT industry labour turnover: the reality. In Proceedings of the 10th International Conference on Sri Lanka Studies, University of Kelaniya, Kelaniya, December 16 (Vol. 18).

Lee, H. \& Cummings, G. (2008), Factors Influencing Job Satisfaction of Front Line Nurse Managers: A Systematic Review. Journal of Nursing Management, 16:768-783.

Luthans, F. (2002). Organizational Behavior. (9th ed). New York: McGraw-Hill International Companies Inc. 
Miller, J. G. \& Wheeler, K G. (1992). Unraveling the mysteries of gender differences in intentions to leave the organization. Journal of Organizational Behavior, 13(5): 465- 478 .

Njenga, L. N. (2014).The Effect of Work Life Balance Policies on women Employees Retention in United Nations Development Program-Somalia.

Park, H. Y., Ofori-Dankwa, J. \& Bishop, D. R. (1994). Organizational and environmental determinants of functional and dysfunctional turnover: Practical and research implications. Human Relations, 47(3): 353-366.

Pasewark, W. R. \& Viator, R. E. (2006). Sources of Work- Family Conflict in the Accounting Profession. Behavioral Research in Accounting, 18, 147-165.

Pitt, L. F. \& Ramaseshan, B. (1995). Realistic job information and sales force turnover: an investigative study. Journal of Managerial Psychology, 10(5): 2936.

Quarles, R. (1994). An examination of promotion opportunities and evaluation criteria as mechanisms for affecting internal auditor. Journal of Managerial Issues, 6(2): 176-194.

Ratna, R \& Kaur, T (2016) The impact of Information Technology on Job Related Factors like Health and Safety, Job Satisfaction, Performance, Productivity and Work Life Balance. J Bus Fin Aff 5: 171. doi:10.4172/2167-0234.1000171

Schaufeli, W. B. \& Bakker, A. B. (2004). Job Demands, Job Resources, and Their Relationship with Burnout and Engagement: A Multi-Sample Study, Journal of Organizational Behavior, 25(3):293-315.

Shagvaliyeva, S. \& Yazdanifard, R. (2014). Impact of Flexible Working Hours on Work-Life Balance, 4(1), 20-23, doi: 10.4236/ajibm.2014.41004.

Singh, J., Goolsby, J. R., \& Rhoads, G. K. (1994). Behavioral and Psychological Consequences of Boundary Spanning Burnout for Customer Service Representatives Trait Perspective”. Journal of Retailing, 85(4):480-492.

Virick, M, Lily, JD \& Casper, WJ (2007). Doing more with less: An analysis of work life balance among layoff survivors, Career Development International, 12(5), 463-80.

Wanninayake, M.S. (2017). Women's labour force Participation in Sri Lanka, International Journal of Social Science and Humanity, 7(3), 184-187

Wei, L.T. \& Yazdanifard, R., (2014). The impact of Positive Reinforcement on Employees' Performance in Organizations, 04, 9-12.

Wetland, D. (2003). The strategic training of employee's model: balancing organizational constraints and training content. In S.A.M. Advanced Management Journal, winter, Cincinnati. 103-107.i 